$\begin{array}{ll}\text { Abstracta Iranica } & \begin{array}{l}\text { Abstracta Iranica } \\ \text { Revue bibliographique pour le domaine irano-aryen }\end{array} \\ & \text { Volume } 22 \mid \mathbf{2 0 0 1} \\ & \text { Comptes rendus des publications de } 1999\end{array}$

\title{
Pâdyâvand. Costa Mesa, CA, Mazda, 1996, 3 vol. 510 p., 655 p., 606 p.
}

Florence Hellot

\section{(2) OpenEdition}

1 Journals

Édition électronique

URL : http://journals.openedition.org/abstractairanica/37401

DOI : 10.4000/abstractairanica.37401

ISSN : 1961-960X

Éditeur :

CNRS (UMR 7528 Mondes iraniens et indiens), Éditions de l'IFRI

\section{Édition imprimée}

Date de publication : 15 mai 2001

ISSN : 0240-8910

\section{Référence électronique}

Florence Hellot, « Pâdyâvand. Costa Mesa, CA, Mazda, 1996, 3 vol. 510 p., 655 p., 606 p. », Abstracta Iranica [En ligne], Volume 22 | 2001, document 312, mis en ligne le 18 février 2010, consulté le 13 octobre 2020. URL : http://journals.openedition.org/abstractairanica/37401 ; DOI : https://doi.org/ 10.4000/abstractairanica.37401

Ce document a été généré automatiquement le 13 octobre 2020.

Tous droits réservés 
Pâdyâvand. Costa Mesa, CA, Mazda, 1996, 3 vol. 510 p., 655 p., 606 p.

Florence Hellot 
Ces trois ouvrages soutenus par The Graduate Society Foundation de Los Angeles représentent une somme très intéressante sur les Iraniens de religion israélite. Ils sont composés d'articles écrits par des spécialistes de la question qui s'efforcent de couvrir l'histoire des Juifs d'Iran depuis les temps reculés jusqu'à la Révolution islamique. Certains auteurs couvrent plusieurs périodes en poursuivant leurs réflexions d'un volume à l'autre et fournissent les documents et les références bibliographiques indispensables aux chercheurs 䂑 la communication par Amnon Netzer de ses propres archives est en particulier très appréciable. Ces articles sont longuement développés en persan sur 367, 389 et 404 pages et présentés en anglais, ce qui les rend accessibles à de nombreux lecteurs. Ils nous font parcourir l'histoire des communautés juives d'Iran aux différentes époques de l'histoire de l'Iran et, d'un point de vue linguistique, percevoir l'apport des dialectes judéo-persans à la compréhension de la langue persane (G. Lazard) ou à celle des serments (Sorur S. Sorudi). Les œuvres des prosateurs et

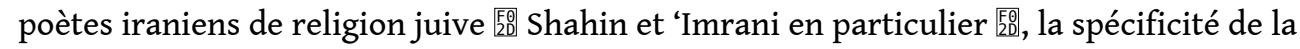
secte karaite et le journal Shalom sont clairement présentés. Les problèmes juridiques liés au passage d'une religion à l'autre touchent les juifs, comme les chrétiens. Le rôle joué par l'Alliance Israélite Universelle à partir des années 1860 peut être rapproché de celui des puissances étrangères en Perse. Il aurait été intéressant d'exploiter aussi les dépêches des représentants français en Perse parce que, si elles font écho aux affrontements inter-communautaires de la fin $\mathrm{du} 19^{\mathrm{e}} \mathrm{s}$. ou du $20^{\mathrm{e}} \mathrm{s}$. signalés dans certains articles, elles sont assez clairement rédigées pour relativiser la portée de l'intervention française. Le soulèvement contre les juifs de Shiraz, en juin 1910, décrit dans les Mémoires de Bașīrat Yūsef, est ainsi évoqué dans les archives françaises. Les représentations sont bienvenues et chaque article mériterait d'être consulté: ils représentent une notable avancée dans la connaissance des Iraniens israélites d'Iran, connaissance à laquelle Homā Nāteq a récemment apporté sa contribution.

\title{
INDEX
}

Thèmes : 6.3. Autres religions

\author{
AUTEURS \\ FLORENCE HELLOT
}

Paris 